\begin{tabular}{|l|l|l||}
\hline \multicolumn{2}{|c|}{ PublisherInfo } \\
\hline \hline PublisherName & $:$ & BioMed Central \\
\hline \hline PublisherLocation & $:$ & London \\
\hline \hline PublisherImprintName & $:$ & BioMed Central \\
\hline \hline
\end{tabular}

\title{
HHMI to recruit 50 new fellows
}

\begin{tabular}{|l|l|l||}
\hline \multicolumn{2}{|c|}{ ArticleInfo } \\
\hline \hline ArticleID & $:$ & 4954 \\
\hline \hline ArticleDOI & $:$ & $10.1186 /$ gb-spotlight-20040519-02 \\
\hline \hline ArticleCitationID & $:$ & spotlight-20040519-02 \\
\hline \hline ArticleSequenceNumber & $:$ & 306 \\
\hline \hline ArticleCategory & $:$ & Research news \\
\hline ArticleFirstPage & $:$ & 1 \\
\hline \hline ArticleLastPage & $:$ & 3 \\
\hline \hline & & RegistrationDate : 2004-5-19 \\
\hline ArticleHistory & $:$ & OnlineDate \\
\hline \hline ArticleCopyright & $:$ & BioMed Central Ltd2004-5-19 \\
\hline \hline ArticleGrants & $:$ & \\
\hline \hline ArticleContext & $:$ & 130594411 \\
\hline \hline
\end{tabular}




\section{Edward Winnick}

Email: Edw10024@yahoo.com

With its endowment recovering from a dip many foundations saw several years ago, the Howard Hughes Medical Institute (HHMI) said last week that it would launch a campaign to back the research of up to 50 new scientists, marking its first major recruitment effort in 4 years and a major investment by the institute.

HHMI's annual research budget is around $\$ 500$ million, and it expects to pump as much as $\$ 350$ million in additional support into the biomedical research community over the next 7 years, according to Thomas R. Cech, the institute's president.

The campaign comes at a time when HHMI's endowment has seen a significant rebound from the hit it took during the previous couple of years. "Like other nonprofits, our endowment took a bit of a dip. But we now feel very strong and confident, and this is a wonderful opportunity for us to hold a general competition," HHMI spokesperson Avice Meehan told us.

The philanthropic organization had a more specialized competition in 2001, but this time it is seeking researchers from a wide variety of specialties and disciplines. "We are looking across all areas of inquiry, because there are many disciplines that one might not in the past have connected to biomedical research. You have physicists and engineers and lots of people who are doing work that links very well with biomedical research," Meehan said.

The Chevy Chase, Md.-based institute currently supports the work of 318 researchers and staff members at 66 universities, medical schools, and research institutes. It has contacted almost 200 such entities seeking nominations for the competition.

As of August 31, 2003, HHMI's endowment stood at $\$ 11.3$ billion, a greater than $10 \%$ gain from its 2002 low of nearly $\$ 10$ billion. Like most other endowments, HHMI's rebound can be tied somewhat to the stock market recovery during late 2003-early 2004.

"Like many other institutions, we are not simply invested in the stock market. But in the course of a single fiscal year, the endowment rebounded more than $10 \%$," Meehan said.

The gain made by the HHMI's endowment over the past year is not a surprise to experts who track the field. In a survey conducted by the Wilton, Conn.-based Commonfund Institute - which provides research, fund management, and investment advice to nonprofits, endowments, and academic institutions - grant-making foundations experienced, on average, a greater than 17\% rebound in 2003 , while stocks were up roughly $28 \%$ for the year.

However, John Griswold, executive director of the Commonfund Institute, told us, "If you go back 3 or 4 years to all of the losses... most foundations are probably still down substantially, in the 10 to $20 \%$ range from where they were in 1999."

"Grantmaking is still down... funds are still down from 4 years ago, and they've got to be cautious," Griswold said. 
But HHMI's Meehan said the institute is "very confident" in its endowment and it is not worried about launching the recruitment competition.

The institute's expanding research budget will grow even larger once its new Janelia Farm Research Campusin Ashburn, Va., becomes operational in 2006. In addition to the most recent call for scientists, HHMI is planning a major recruitment effort in the fall to staff the Janelia facility.

"We anticipate it's going to be a very different kind of research community, [with] very small lab groups where senior scientists are still doing bench research," Meehan said. She said the Janelia facility would be fully staffed around 2009-2010 and would employ roughly two dozen research groups that will likely have six to eight people in each group.

\section{References}

1. "Howard Hughes Medical Institute seeks up to 50 new scientists," Howard Hughes Medical Institute press release, May 13, 2004., [http://www.hhmi.org/news/051304.html]

2. Commonfund Institute, [http://www.commonfund.org/Commonfund/]

3. Janelia Farm Research Campus, [http://www.hhmi.org/janelia/]

This PDF file was created after publication. 